\title{
The Contribution of the International Coffee Agreement (ICA) to the Development of Export Markets for Small Scale Coffee Farmers in Manicaland, Zimbabwe
}

\author{
Stanislas Bigirimana \\ Faculty of Management and Administration, Africa University \\ PO BOX 1320, Mutare, Zimbabwe \\ E-mail: sbigirimanaus@yahoo.com \\ Reason Masengu \\ Faculty of Commerce, Midlands State University \\ P. Bag 9055, Gweru, Zimbabwe \\ E-mail: masengumasengu@yahoo.com
}

Received: May 16, 2015

doi:10.5296/wjbm.v1i1.7931
Accepted: June 24, 2015

Published: June 25, 2015

URL: http://dx.doi.org/10.5296/wjbm.v1i1.7931

\begin{abstract}
:
The International Coffee Agreement (ICA) aimed at strengthening the global coffee sector through the promotion of its sustainable expansion in a market-based environment for the betterment of all participants in the sector. This goal was meant to be achieved through five strategies, namely, (1) promoting international cooperation on coffee matters, (2) encouraging consumption that balances demand and supply, (3) providing market development, (4) facilitating fair-trade and (5) enhancing coffee financing for small scale farmers in developing countries. An exploratory study aiming at assessing to what extent the ICA has contributed to the development of export markets for small scale coffee growers in Manicaland, Zimbabwe showed that the ICA is failing to promote international market development. $99 \%$ of the respondents agree that it is doing it to a lower extent. This study recommends that the ICA should put in place a platform to incorporate the small scale farmers so that they increase their market spectrum in order to increase its export volumes and sustain the sector.
\end{abstract}

Keywords: The international Coffee Agreement (ICA), Small Holder Farmers, Fairtrade, Market Development, Sustainabilit 


\section{Introduction}

The International Coffee Agreement (ICA) is an agreement or set of regulations between the principal coffee exporting and importing countries that imposed export quotas in order to raise the price at which member country exporters sell coffee to member country importers. Member importing countries have accepted the higher prices paid by their consumers in order to benefit government and farmers in less developed coffee exporting countries (ICA 2011).In spite of this effort by the international community to stabilize the coffee market, there is a continued decline in production, failure to enter into international markets, lack of coffee financing and a general decline in coffee consumption and the livelihood of small scale farmers is generally declining. In view of the coffee exports decline there was an international attempt to regulate the coffee market through the use of a quota system, however this had failed to stabilize the coffee market hence this lead to the crafting of the ICA in 2007.

The objective of the ICA 2007 is to strengthen the global coffee sector and promote its sustainable expansion in a market-based environment for the betterment of all participants in the sector, by promoting international cooperation on coffee matters. It also aims to encourage consumption that balances demand and supply, providing market development, facilitating fair-trade and to enhance coffee financing for small scale farmers in developing countries. In addition to this the ICA promotes improvement of coffee quality through training and information designed to assist transfer of technology to its members (ICA 2007).

These set ICA objectives were put in place to assist coffee growers in less and developing countries in Southern hemisphere who are highly affected by the volatility of the market and coffee consumers in the northern hemisphere who are mainly the intermediaries and major consumers of coffee. In response to the decline of small scale coffee farmer's exports in developing countries several researches were done in the SADC region with an objective of coming up with strategies to increase small scale farmers participation in the international coffee trade. This study aims at assessing the contribution of the International Coffee Agreement (ICA) on the development of export markets for Small Scale Farmers in Manicaland, Zimbabwe.

\section{Formulation of the Problem}

Despite the efforts made by ICA to promote coffee growing and coffee exports, coffee production and exports are on a free-fall decline in Zimbabwe. This research therefore seeks to evaluate the extent to which The ICA had contributed to the development of exports markets for small scale coffee growers in Manicaland, Zimbabwe.

\section{Objective of the Study}

The aim of this paper is assess the contribution of the ICA to the development of exports markets for small scale growers in Manicaland, Zimbabwe. 


\section{Literature Review}

Taderera (2011) defines export as shipping of goods and services out of the country of origin in which the seller of the goods is referred to as the exporter who is based in the country of import whereas buyer is referred to as an importer. Kruger (2010) adds that export is a function of international trade whereby goods produced in one country are shipped to another country for future sale or trade and the sale of such goods adds to the producing nation's gross output. The Swedish Customs (2010) alludes that export is a process of taking goods or services out of the European Union (EU) to a foreign market which does not belong to that trading block for further use or consumption.

Taderera (2010) argues that non-exporters consider the lack of knowledge of potential markets, lack of qualified export personnel, lack of technical suitability, degree of competition in the sector, lack of financial assistance (governmental and financial institutions), and lack of qualified human resources as the main export barriers restricting the motive and ambition for small scale farmers to sell their produce to international markets. Arnold and Raphael (2013) adds that firms need to focus on processes and organizational structures in transportation management with special focus on the integration of existing commercial Transportation Management Systems (TMS) so as to make big savings and remain competitive in the current cut throat competition environment in the international market and be in a position to increase its export volumes and enjoy competitive advantage.in view of the above reason for exporting it is apparent to note that exporters needs to enhance the supply chain in which product move from the source to the final user in order to enjoy economies of scale.

Determinants of export volumes range from the effects of exchange rates, international marketing activity, access to transport infrastructure and trade liberalization as pivotal in determining export volume. Lui and Yi (2013) define exchange rates in two types used extensively in international trade namely spot and forward exchange rate. The bilateral spot exchange rate is the rate at which forex can be bought and sold for immediate delivery convectional in 1 or 2 days while bilateral forward exchange rate is the rate negotiated today at which foreign exchange can be bought and sold for delivery sometime in the future. In addition to this Arkolakins (2011) states that exchange rate is the price of some foreign currency in terms of home currency. Miller (2010) finds out that movement in exchange rates affect export in the sense that depreciation raises exports, but the associated exchange rate risk could offset that positive effect. Depreciation of the exchange rate lowers the foreign currency price of exports and increases the quantity of exports and export revenue in domestic currency. In addition to this Wilson (2007) reveal that devaluation increases exports for developed countries with fixed exchange rate.

Maerk (2007) argues that the exchange rate influences both the supply and the demand of export volume. However as many of the country's export are priced in forex changes in the home currency do not automatically affect demand for exports since firms have a tendency of charging different prices in connection to volatility of exchange rate. Wang and Barret (2007) adds that exporter serving niche market may keep the prices relatively 
constant despite rise in the exchange rate with the will of controlling the market forces. A positive move in the exchange rates attracts greater returns to exporter while at the same note a depreciation of the exchange rate reduces the return on export and will have negative impact to export volumes. Exporter would favor a situation in which the exchange rate appreciates in their favor in order increase their revenue

Berthou (2007) defines trade liberalization as a move towards free trade through the reduction of tariffs and other barriers and is generally perceived as the major driving force behind globalization. Alves and Lawrence (2005) say that trade liberalization as the removal or reduction of restrictions or barriers of trade on the exports and imports among different trading partners. All the authors agree that trade liberalization involves the removal of trade barriers hence opening up new markets to increase export volumes. Tybout (2010) emphasizes that trade integration reallocates market shares toward exports, the most productive firms, increase their aggregate productivity resulting in increased revenues which can increase exports volumes and the potential to invest in new technology. In line with this argument were Lui and Yi (2010) who indicates that developing countries not only import more after liberalization their trade regime but also export more hence liberalization lead to higher import growth than export growth possibly leading to a deteriorating in the overall trade balance. Bouef (2008) argues that expected benefits of trade liberalization to exports are surprising low, in fact its consequences are modest because rich countries compose a major part of this income due to the fact that they are already close to free trade. He added that trade liberalization may have more substantial impact on developing countries by comparison, the Asian miracle, Chile experience, and China all brought high export growth rates per annum but developing countries especially in Africa have failed to harness the substantial benefits of globalization of markets. Liberalization has been credited for the most economics fortune but it is important to note that it has been blamed it for a host of ills as rising unemployment and wage inequality in the advanced countries and a race to a the bottom in respect to employment conditions and labor standards, increased poverty, global inequality which are counter increase export volumes in most developing countries.

Helm (2010) defines infrastructure as what lies between companies and market and between consumers and essential services which incorporates core network utilities like transport, energy, water and communication. Buhr (2011) citing Jochimsen (1966) argues that infrastructure is the sum of material, institutional, personal facilities and data which are available to the economic agents which contribute to realizing the equalization of remuneration of comparable input to an economic activity. Helm (2014), and Buhr (2011) agrees that infrastructure is key to the successful movement of goods and services across national boundaries and it is integral in that an efficient and effective infrastructure system increase the export of product. Mohlomi (2009) found that in Lesotho takes approximately 45 days in order to transport apparel products from factories in Lesotho to the United States markets. Part of the delay on exporting goods out of the country stems from "soft" infrastructure impediments, such as custom procedures at the border between Lesotho and South Africa and also physical infrastructure constraints such as lack of adequate bridge linking approved producing regions to nearly transportation routes. 
In a related note Helm (2014) adds that poor conditions in Chad's road and electricity infrastructure constrain the country's social and economic development affect the country' export competiveness. He also alludes that large regions of Chad are effectively cut off from one another during rainy season and that they is limited capacity to transport commodities such as grain to export markets and this also affected competitiveness of livestock, sugar and textiles export competiveness. Adams (2010) argues that it is prudent to review the procedures or soft infrastructure that are in place at various border crossings points in order to reduce border delays and increase movement for exports. He said that a one stop border post is important step to develop the full potential of land transport corridors because such posts reduce costs by decreasing transaction times of redundant bureaucracy between two (2) countries hence improving the ability of small industries to export into international market.

Arnold and Raphael (2010) argue that poor infrastructure conditions increase production costs, economic distance and business uncertainty, and undermine Sub Saharan Africa (SSA)'s export competitiveness. In addition to this Mohlomi (2009) indicates that most roads in SSA are poorly maintained and often unpaved, and truck fleets generally consist of aging, fuel-inefficient vehicles that are often overloaded and contribute to further road degradation. Poor roads and truck breakdowns result in the slow movement of goods, considerable damage to goods in transit and increased shipping costs relative to other areas of the world. It is therefore apparent to note from the above scholars that the success of participating in the international trade for most developing countries is hinged on the ability of these countries to improve infrastructure conditions due to the fact that their competitive advantage is weaken by poor infrastructure conditions.

\section{Research Methodology}

\subsection{Research Philosophy}

The researcher used pragmatism as the research philosophy in order to fuse multiple methods of data collection to inform the problem understudy.

\subsection{Research Design}

The researchers used exploratory and descriptive research designs. Exploratory research design was used to explore the objectives made by ICA in regard to the promotion of international market development. It enabled the used of research instrument such as interviews, focus groups, observation and the examination of similar situations to get a broad picture of the subject matter. Descriptive research design allowed the researcher to describe the population under study and it helped in answering who, where, what, when and how of the decision problem. Descriptive research design also facilitated on how the ICA was implementing its policies in line with the objectives set by the International Coffee Organisation.

\subsection{Population and Sampling Techniques}

The populations encompassed individuals and companies whom the researcher is interested in obtaining and making inferences. This research target population included all coffee 
farmers in coffee institutions in Zimbabwe. The coffee farmers who are under study are small scale farmers with an average coffee hectarage of 1-2 hectares. A pilot study showed that the majority of the small scale coffee farmers are in the Manicaland Province although pockets of these farmers can be found in other provinces such as Matebeland and Mashonaland. The pilot study also indicated that are three institutions who are involved in coffee export namely G.M.B, Zimbabwe Coffee Mill and Coffee research Centre. The sample included small scale farmers who supply their coffee G.M.B, Zimbabwe Coffee Mill and who are affiliated to the Coffee research Mill and management at the three institutions. Strata were made using homogenous characteristics and judgmental and snow ball sampling were used for different stratum. The sample included 6 managers at Mutare coffee Mill, Coffee Research Centre, and GMB Mutare Coffee and 50 coffee small scale farmers who were chosen from Manicaland using snowball sampling and simple random sampling procedures. The researcher used non probability and probability techniques namely purposive, snowball and simple random sampling techniques in the study but largely depended on non-probability sampling methods. Purposive sampling was applied in this research due to the fact that the population which is involved is small and well defined. In Manicaland the researcher engaged G.M.B management, Mutare Coffee Mill and Coffee Research Centre since they the only in institution dealing coffee small scale farmers. However, since it is based on the researcher's judgment chosen respondents may be biased hence giving inappropriate answer to please the researcher. The researcher selected the initial group at random and interviewed the respondents were asked to identify other farmers who belong to the target population of interest. The researcher used networks in small scale farming as reference until the sample size was achieved.The researcher used table of random numbers that ensures that each sampling unit has a known, equal and non-zero chance of getting selected in the sample. It involved putting small pieces assigning numbers to each target company then pick at random each sampling unit to identify the person to be interviewed. However the procedure may not cover an effective area of the sample. The researcher used this procedure in selecting the small scale farmers.

\begin{tabular}{|c|c|c|c|}
\hline Population & Target population & Sample Frame \\
\hline G.M.B management & Management & 5 & 2 \\
\hline Zimbabwe Coffee Mill & Management & 4 & 2 \\
\hline Coffee Research Centre & Management & 5 & 2 \\
\hline Farmers & Small scale farmers & 50 & 30 \\
\hline \multicolumn{2}{|}{ TOTAL SAMPLE } & & $\mathbf{5 6}$ \\
\hline
\end{tabular}

\subsection{Data Collection Techniques and Instruments}

In this research both primary and secondary data were used in undertaking the research question.

In order to receive information about the specific target group, the researcher decided to carry out descriptive surveys for gathering statistical information about attributes, attitudes and actions of the population by administering standardized questionnaires to some of its 
members. Self-administration of the data collection process allowed the researcher the opportunity to answer queries with regard to completion of the questionnaire which latter increased the response rate. The major research instruments to be used by the researcher in the research are in depth interviews, questionnaires and focus groups.

\subsubsection{In Depth Interviews}

The research used in depth interviews in probing information from respondents from three stated coffee institutions with the major aim to identify how policies are being implemented to achieve the ICA objectives. It enables the research to have the ability to probe on the challenges facing the small scale farmers and understand strategies which were implemented to overcome the problems facing coffee small scale farmers. It also helped the researcher in understanding how ICA was assisting small scale farmers in accessing international markets with the view of promoting consumption of coffee especially to countries with low coffee intake.

\subsubsection{Questionnaires}

The researcher used questionnaires to small scale farmers. The research used questionnaires to solicit information about the challenges which small scale farmers are facing in increasing their export volumes. Self-administration of questionnaires increased the response rate of the questionnaire since the researcher was dealing directly with the management. The researcher used close ended questions in order to control responses. The researcher gathered data using structured questionnaire in order to capture the desired information and to improve on data quality. The major consideration for applying self-administered questionnaire was to administer large numbers of respondents and improving the accuracy of the results. Questionnaires enabled the researcher to be cost effective, convenient in data collection, ensuring uniformity and anonymity. A questionnaire also allows the gathering of quantitative data.

\subsubsection{Focus Groups}

The researcher to gathered a small number of eight (8) to ten (10) members of small scale coffee farmers for a discussion in order to get an in-depth understanding of the problem. The researcher organized 3 groups of small scale coffee farmers in order to have a clear understanding of their ideas, opinion in regard to what the ICA should put in place to improve productivity and export volume. The researcher gathered vast amount of information on ideas, feeling and experience about the impact of ICA to small scale farmers coffee exports. Focus group were also applied in the study in order to understand issues to do with coffee financing projects and market development due to the fact that each group was given enough time to precisely highlight the impact of participating the international trade of coffee. Focus group enabled the researcher to have an vast array of information since it selects respondents from same stratum which helps ensure that group members feel at ease with each other who can divulge their opinions clearly. On the same vein diverse groups were selected to encourage cross pollination of points relating the researcher's concepts. However the participation of the focus group was difficult since some members were not willing to share 


\section{Al Macrothink}

World Journal of Business and Management

ISSN 2377-4622

2015, Vol. 1, No. 1

their experience due to the fact that they wanted to maintain their privacy in regard to challenges they were facing in coffee production.

\section{Findings}

The research sought to evaluate the extent to which ICA promote market development at different levels and the following table shows the findings.

Table 1. Showing responses on the extent to which ICA promotes international market development

\begin{tabular}{|l|l|c|c|c|c|}
\hline & Level & Lower extent & Moderate & Greater extent & Total \\
\hline Domestic market expansion & Regional & $100 \%$ & $0 \%$ & $0 \%$ & $100 \%$ \\
\hline & Domestic Exports & $96 \%$ & $4 \%$ & $0 \%$ & $100 \%$ \\
\hline International market entry & International exports & $100 \%$ & $0 \%$ & $0 \%$ & $100 \%$ \\
\hline & $\begin{array}{l}\text { International market } \\
\text { access }\end{array}$ & $100 \%$ & $0 \%$ & $0 \%$ & $100 \%$ \\
\hline Averages & & $99 \%$ & $1 \%$ & $0 \%$ & $100 \%$ \\
\hline
\end{tabular}

The above information is summarized on the figure below:

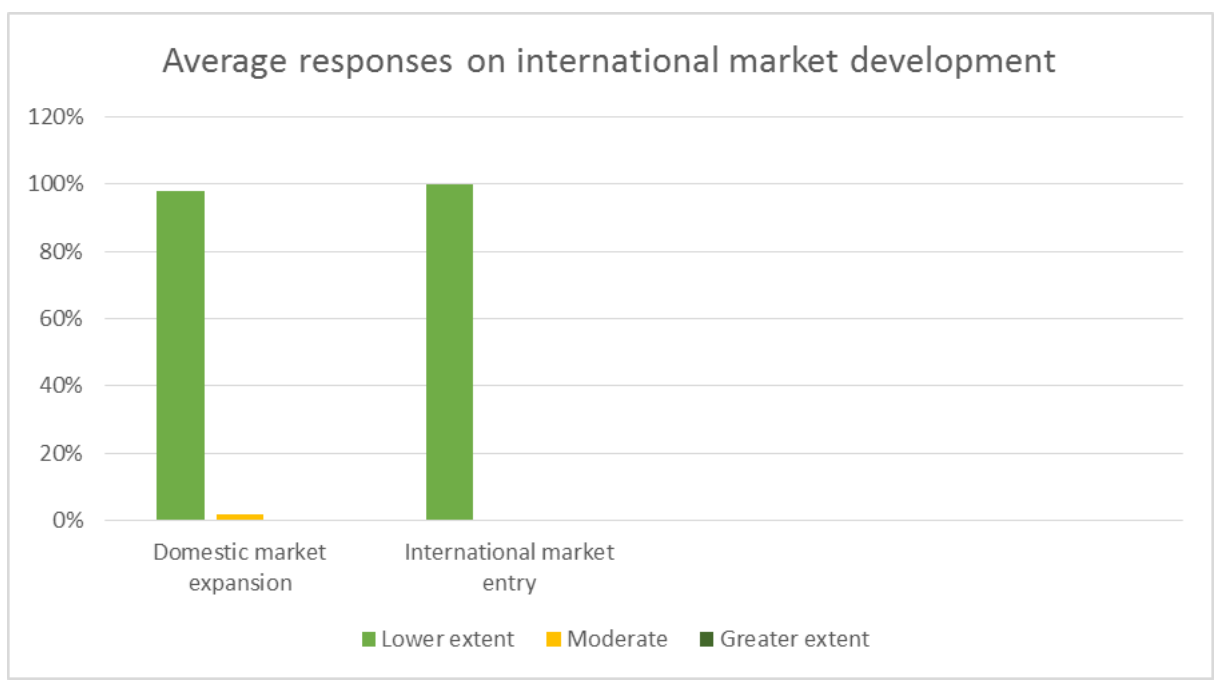

Figure 1. Showing the extent to which ICA promote international market development

The researcher asked the respondents the extent to which ICA promoted coffee market expansion in the region and the results were as follows $100 \%$ rated to a lower extent. In responses to the extent to which the ICA promoted domestic market expansion the results $96 \%$ rated lower extent and $4 \%$ rated moderate. This is supported by findings from interviews where farmers revealed that no organization has been instrumental in developing their markets to regional markets and small scale farmers were facing stiff competition within the 
region like South Africa and Angola who are selling subsidized coffee to the market hence creating price walls. In response to the question of the extent to which ICA had facilitated the export of coffee into international market the results were that, $100 \%$ rated to a lower extent. Focus groups conducted also conducted revealed that the farmers were still being hindered in their export due to restrictive international trade barriers and such as huge tariffs and complicated documentation procedures which are beyond the comprehension of the rural coffee farmers. The research further asked the respondents the extent to which ICA promoted export of coffee to international market the results were as follows $100 \%$ rated lower extent. The result to the extent to which ICA facilitated the participation of small scale farmers in international coffee market the results were as follows $100 \%$ rated to a lower extent.

Averagely as depicted by the table 4.4 above the majority respondents agree that ICA is doing very little in helping small scale coffee growers expand into international markets. A total of 99\% respondents concur that it is to a lower extent and only $1 \%$ of the respondents going for the moderate response. Discussion from small scale farmers indicated that ICA was failing to have an outreach programmes to educate these farmer on how to access these markets and farmers were not even aware of the intended markets of their coffee due to limited interaction between famers and the market as shown from interview findings.

\section{Conclusions}

ICA is failing to promote distinctive coffee consumption to small scale farmers. Based on the findings, that on average $90 \%$ of the responses concur that ICA is promoting coffee consumption to a lower extent and an average of $7.5 \%$ agree that it is to a moderate extent and $2.5 \%$ greed that ICA is promoting the consumption of coffee to a greater extent. ICA is promoting conspicuous coffee consumption to a larger extent. The majority of the respondents $(65.5 \%)$ agree that ICA promote conspicuous consumption to a very great extent. ICA is promoting compulsive consumption to a moderate extent as an average of 49.6\% agree that it is achieving it to a lower extent with $17.5 \%$ showing that it is to a moderate extent and $33.5 \%$ respondents showing that it is to a lower extent. ICA is failing to promote international market development basing on the findings that $99 \%$ agree that it is doing it to a lower extent. The ICA should put in place a platform to incorporate the small scale farmers so that they increase their market spectrum in order to increase its export volumes and sustain the sector.

\section{References}

Adams, B. (2010). Proceeding of the 9th workshop on aspects, components and patterns of infrastructure. Universitatsverlag Potsdam Netherlands.

Alves, E., \& Lawrence, R. (2005). South Africa export performance: Determinants of export supply. University of Cape Town, South Africa.

Arkolakins, C. (2011). Exchange rate economics (vol. 407). Yale University.

Arnold, R., \& Raphael, S. (2010). Institutional Architecture to improve system operations and management transportation. Leicester research board, Report S2-L06-RR-1. 


\section{Macrothink}

World Journal of Business and Management

ISSN 2377-4622

2015, Vol. 1, No. 1

Berthou, A. (2008). An investigation on the effect of real exchange rate movements on OECD bilateral exports. working paper series No 920, European Central bank, Germany.

Bouf, A. (2008). The expected benefits of trade liberalization for world income development (Vol. 332). Alan Treat United states of America International Trade Commission, Washington Dc.

Haule, G., \& Baur, S. (2010). Whither Small scale farmers in Africa. SADC Journal on Agricultural Productivity, 10.

Helm, D. (2010). Infrastructure, investment and economic crisis. Policy Exchange Journal, London.

International Coffee Agreement. (2007, 2011). International Coffee Agreement Publishers, London, England.

Lui, Q. (2013). Do experts respond to exchange rate changes? University of international business and economics, Beijing China.

Maerk, P., \& Taylor, S. (2007). The economics of exchange rate. UK: The Cambridge press.

Mahlomi, M. (2009). Sub Saharan effects of infrastructure condition on exports competiveness. The SADC annual report $40 / 7$

Miller, M., \& Paul, K. (2010). Exchange rate targets and currency bands. United Kingdom: Cambridge University Press.

Swedish Customs. (2010). Export Guide Handbook. Sweden: Sweden Government publishers.

Taderera, F. (2011). The pillars of applied exports and international business. UK: Limbert publishing.

Tybout. (2010). Is Learning by Exporting Important? Micro-dynamic Evidence from Colombia, Mexico and Morocco. Quarterly Journal of Economics, 133, 903-947.

Wang, C., \& Bariet, C. (2007). GARCH model with an application to exchange rate. International Monetary Journal on Exchange Rate, 50.

Wilson, P., \& Tat, C. (2001). Exchange rates and the trade balance: The case of Singapore 1970 to 1996. Journal of Asian Economics, 12, 47-63. http://dx.doi.org/10.1016/S1049-0078(01)00072-0

\section{Copyright Disclaimer}

Copyright for this article is retained by the author(s), with first publication rights granted to the journal.

This is an open-access article distributed under the terms and conditions of the Creative Commons Attribution license (http://creativecommons.org/licenses/by/3.0/). 